\title{
ROLE OF MaaS IN TOURISM
}

\section{Ivana Martinčević Predrag Brlek Nives Domjan}

https://doi.org//10.20867/tosee.06.34

\begin{abstract}
Purpose - The occurrence of bottlenecks, congestion, increased fuel consumption and environmental pollution are the basic problems of large urban areas, especially when it comes to tourist areas where with the local population roads are used by visitors who, during or after a stay are looking for some way of transportation. Regardless of the final destinations, the tourist activity strives to meet the needs and requirements of visitors to the maximum, so their offer must be attractive, fast and accessible at all times, as well as adaptable to changes in travel habits. With regard to the specific criteria of the local economic, social and environmental policy mobility services should be adapted to different target groups, including a unique travel option that would facilitate the stay of tourists. The aim of this paper is to: (1) explore MaaS concept (2) explore the importance and benefits of MaaS concept (3) and to explore the importance and benefits of MaaS concept in area of tourism.

Methodology - In order to investigate and achieve the set goals, world and Croatian literature was used and analyzed by searching the databases such as Wos, Scopus, Google Scholar, using the search phrase ("mobility as a service" OR sustainable development) AND ("transport" OR "tourism"). For this purpose, a survey was conducted to explore the importance of MaaS in the field of tourism on the basis of which the advantages and benefits of the mentioned concept as one of the main conditions for sustainable development were analyzed.

Findings - As no research has been conducted in the territory of the Republic of Croatia that investigates the application of the MaaS concept in the field of tourism and its importance and contribution to strengthening tourism, this research contributes to strengthening the awareness of individuals about this concept and its application. The intention and goal of this research was to make aware general public of the importance of the Maas concept. Although MaaS concept is a relatively new concept it takes on increasing importance; therefore, it needs to be strongly and systematically developed further. By analyzing the relevant scientific sources and based on the results of the research, it can be concluded that a strategic approach to the MaaS concept can provide a numerous of advantages and benefits. Recommendations for further research is to include data from other countries of the European Union (EU) or from neighboring countries in order to be able to compare data by specific areas.

Contribution - By introducing the concept of MaaS in the segment of tourism, it opens the possibility for visitors to access a wide selection of public and private carriers through a digital platform. The trip for each user is planned separately according to the previously collected data on the demand and supply of transport services, combining them with information on the preferences of the participants themselves. Simply put, the traveler can plan, book and pay for any trip, anywhere and at any time. Simultaneous planning of tourism and transport is not an easy task because in most cases these plans diverge, but the cooperation of stakeholders of both branches is necessary for more attractive and environmentally friendly measures of sustainable mobility that ultimately affect the development of tourism. The obtained results can be used to expand the current scientific knowledge about the MaaS concept and its impact in file of tourism.

Keywords: mobility, mobility as a service, sustainable development, tourism.
\end{abstract}


ToSEE - Tourism in Southern and Eastern Europe, Vol. 6, pp. 503-516, 2021.

I. Martinčević, P. Brlek, N. Domjan: ROLE OF MaaS IN TOURISM

\section{INTRODUCTION}

Public transport operators have made considerable efforts in recent years to provide a single public transport ticket by enabling all passengers to use the services of different carriers in the same city or region. However, following trends and using new modes of transport, changes in the lifestyle of younger generations, the trend of urbanization, changing consumer expectations, urban innovation, rapid growth of technology - all of the above affects and shapes future mobility. Transport policy makers have been trying for years to make public transport more attractive to allow a gradual transition from private cars to more alternative modes of transport which can mainly be achieved through new modern mobility technologies that must provide a high level of flexibility and accessibility. With the introduction of the new trend "Mobility as a Service" (MaaS), the situation will be visibly different, so the first key change will be that transport users and service providers at some point communicate about their capabilities / needs through a digital platform services. Another key change is the emergence of a whole new package of shared services, which means that users will be freer in terms of their expectations, so multiple operators (multiple types) of transport services will specify more accurate features of the transport service: arrival time, origin and destination, the level of comfort required, the price it is willing to pay, etc. By offering a wide range of services, providers will be able to accept or reject users depending on their expectations, while regulators will easily monitor service availability and adjust market strategy and policy decisions accordingly. This should result in customer-led services that adapt to real market conditions at any time and in any place, to the general benefit of all stakeholders involved. Accordingly, there are also major challenges for policy makers who will need to balance the promised benefits with issues such as security, privacy and the threat of market distortions by unscrupulous service providers.

\section{THE SIGNIFICANCE OF THE CONCEPT MOBILITY AS A SERVICE}

\subsection{History of MaaS}

The concept of Mobility as a service was first presented in 1996 at the ENTER conference in Innsbruck, Austria. The concept is presented as a platform that connects different transport providers with those seeking transport, in terms of a combination, search and travel booking. Given that the Internet as we know it today was limited in the mid-1990s, the concept itself was ahead of its time (Whim 2019). Among the efforts to make the idea of Mobility as a service a reality, Finland and MaaS Global have significantly contributed to the development itself by turning the whole country into a pilot incubator to make the concept a reality.

\subsection{Definition of concept}

Hietanen (2014) describes MaaS as a mobility distribution model that meets the transport needs of users through a single service provider interface and combines different modes of transport to offer a customized package for each passenger individually. This interpretation encompasses some of the core characteristics of MaaS: customer's need- 
ToSEE - Tourism in Southern and Eastern Europe, Vol. 6, pp. 503-516, 2021.

I. Martinčević, P. Brlek, N. Domjan: ROLE OF MaaS IN TOURISM

based, service bundling, cooperativity and interconnectivity in transport modes and service providers (Alonso Gonzales et al. 2017). Holmberg et al. (2016) emphasized the role of subscription in MaaS, giving the user the possibility to plan his / her journey, in terms of booking and paying the several transport modes that might be required, all in one service. To access the service, travelers will be asked to register or make an account At a first level, this is to make booking and payment easier, as the concept envisions a 'seamless' combination of all transportation modes and a 'Mobility Aggregator' that gathers and sells all services through a single smartphone app, allowing easy fare payment and one-stop billing (CIVITAS 2016).

\subsection{MaaS Platform}

MaaS is based on the idea of access through a single medium, smartphone, various mobility services, including public transport and shared mobility services. The concept underlying MaaS is that urban mobility must become fully multimodal, while access to a wide range of services will be coordinated through different service providers, given the fact that the digital revolution can offer new opportunities for all involved ( $\mathrm{Li}$ and Voege 2017). The MaaS platform is a collection of components which perform integral functions such as data import, data storage, journey planning, optimisation, ticketing, payment and communication. These functions allow users to plan multimodal journeys, to book transport assets, to receive on-route guidance and re-booking suggestions in case of disruption, and to pay for the journey in a unified manner. Relevant data concerns, amongst others, locations of public transport stations, routing and timetable information, real-time location of trains, busses, shared-cars and bikes, location and pricing information of ride-hailing services and the respective booking and payment systems of the various modes (ERTICO - ITS Europe 2019). One of the most prominent examples of operational MaaS platforms is „Whim“, developed by Finnish start-up MaaS Global and introduced in Helsinki in 2016. The Whim user can combine, plan, and pay, both in pay-as-you-go or monthly subscription forms, for public transport, taxi, car rental, carsharing, and city bike trips (Alyavina, Nikitas and Njoya 2020). By July 2018, operational for over two years, Whim had been used by around 45,000 Helsinski residents, which accounts for only $7 \%$ of the city`s population (House of Commons Transport Comittee 2018). Whim is now up and running in West Midlands, UK, despite being piloted twice in August 2017, the latest launch of the app received just around 5000 downloads (House of Commons Transport Comittee 2018). The online platforms have a potential to improve consumer choice and convenience, improve efficiency and competitiveness of the industry, and enhance civil participation in society (MaaS Alliance 2019). In the context of digitalization, online platforms are considered key drivers of innovation.

\subsection{Benefits and risks of MaaS}

The move away from private and individual ownership of vehicles to an intelligent and convenient usage of alternative modes of transport, brings about many positives (Duggan, 2019). Important is the fact that the platform issues only one invoice for several modes of transport, so there is no need to record or worry about what is or what is not 
ToSEE - Tourism in Southern and Eastern Europe, Vol. 6, pp. 503-516, 2021.

I. Martinčević, P. Brlek, N. Domjan: ROLE OF MaaS IN TOURISM

paid (BMaaS Contributor 2018). As the Maas encourages people to use common and alternative modes of transport it will greatly reduce road congestion, increasing the overall space. Fewer vehicles on the road have a positive impact on the environment, represent sustainable forms of transport and increase the living standards of residents (BMaaS Contributor 2018). This is a profound shift due to an increase in and the ability to share information, and by new business models becoming possible thanks to technology and a greater willingness among people to try new things (EPOMM 2017). Implementation of MaaS still faces significant challenges on users' perspectives, business model and policy support (Li and Voege 2017).

\section{MaaS IN TOURISM}

\subsection{Tourism and Mobility}

The availability of transport is a decisive factor in choosing the desired destination, so tourism and travel are interdependent components of the social and economic trend of constantly increasing mobility globally (La Roca 2015). Taking Europe as a prime example of a small geographical size but a continent's leading position in terms of tourist travel, creating and implementing new mobility concepts that have room to introduce new and more sustainable travel patterns is central to the future of the European travel and tourism industry. (Tchervenkova 2000)

\subsection{The impact of the MaaS on tourism}

Digital platforms are increasingly used in all segments of tourism, especially when it comes to the travel process itself (Lopez-Cordova 2020). In this way, travelers, especially tourists, always strive for updated information so that they can reach their final destination safely, quickly and cheaply. This is supported by the fact that $74.9 \%$ of Europeans mostly use the "Maps" application, especially if they find themselves in an unfamiliar city. Also, about $30 \%$ of them use public transport applications, while $20.7 \%$ of people use parking applications. Based on all the above, it is concluded that MaaS is much needed, especially when it comes to tourism. Access to all private and public carriers, without language barriers, ease of payment, time savings - all on one platform at your fingertips, in any city in the world (Alexandre 2020).

\section{METHODOLOGY OF EMPIRICAL RESEARCH}

Based on the presented general data and an overview of the concept of the MaaS service through the previous chapters, the importance of the MaaS service in the field of tourism is clear. Systematic application of the MaaS service should result in a better, more efficient and more functional way of traveling. It is possible to assume that if citizens are familiar with the MaaS service and are willing to use it when planning a trip, they can provide faster, innovative and more functional ways and methods of travel compared to others who do not use the MaaS service. Empirical research was conducted through an online survey. The survey was aimed to the citizens of the Republic of Croatia and was 
ToSEE - Tourism in Southern and Eastern Europe, Vol. 6, pp. 503-516, 2021.

I. Martinčević, P. Brlek, N. Domjan: ROLE OF MaaS IN TOURISM

created on the Google-docs platform. Research was conducted during April 2021 via social media and 405 survey questionnaires were collected. According to previous research (Alyavina et al. 2020; Kim et al. 2021; Zijlstra et al. 2020; Liljamo et al. 2021; European Union's Horizon 2020 research and innovation program under grant agreement No. 723176, 2018) survey questionnaire was created and consisting of 6 parts: (1) A set of demographic questions; (2) A set of questions related to mobility modes (public transport, private transport, new transport concepts (car-sharing, car-pooling, bikesharing)) and questions in the domain of using mobile applications related to mobility; (3) Questions related to attitudes about satisfaction with combining modes of transport to reach a tourist destination where each offered statement was evaluated by a Likert scale from 1 to 5 (1 -"strongly disagree", 2 -"generally disagree" ", 3 -" neither agree nor disagree ", 4 -"mostly agree "and 5 -"completely agree"); (4) Questions related to attitudes about satisfaction with the use of mobility applications where each offered statement was evaluated by a Likert scale from 1 to 5 (1 -"strongly disagree", 2 "generally disagree", 3 - "neither agree nor disagree", 4 - "mostly agree" and 5 "completely agree"); (5) Questions related to multimodal way of thinking about travel planning where each offered statement was evaluated by Likert scale from 1 to 5 (1 "strongly disagree", 2 - "mostly disagree", 3 - "neither agree nor disagree", 4 - "mostly agree" and 5 - "completely agree"); (6) Questions related to attitudes regarding the acceptance and use of the MaaS service where each offered statement was evaluated by a Likert scale from 1 to 5 (1 - "it doesn't matter to me at all", 2 - "mostly it doesn't matter to me", 3 - " it is neither important nor unimportant to me", 4 - "mostly it is important to me "and 5 -" it is very important to me"). The collected data were statistically processed using two programs SPSS and MS Excel.

\section{ANALYSIS OF THE RESULTS OF THE RESEARCH - MaaS IN THE FUNCTION OF TOURISM}

The research part of this paper includes a survey conducted in the Republic of Croatia whose goal was to examine the general awareness of citizens about ways of mobility as well as explore a new concept in a field of mobility and that is the MaaS service. The survey consists of 36 questions divided into 6 sections. The introductory part of this chapter presents data dealing with a set of demographic questions while the paper further focuses on the analysis and processing of questions related to the MaaS service as a key concept of this research. The survey shows the gender structure of the respondents where $30 \%$ men and $70 \%$ women. Regarding the age of the respondents, the majority are aged from 16 to 25 and that is $33 \%, 29 \%$ respondents were from 26 to 35 while only $0.5 \%$ are older than 65 . The level of completed education shows that the most respondents have higher education (faculty) $45 \%$, followed by secondary vocational school with $30 \%, 13 \%$ of respondents have completed high school, while $8 \%$ have master of science and $4 \%$ are doctorate of science $(4 \%)$.

\subsection{Descriptive research results}

Regarding general awareness about the MaaS service, the results indicate that $87 \%$ of respondents are not familiar about MaaS service while $13 \%$ are familiar with the MaaS 
ToSEE - Tourism in Southern and Eastern Europe, Vol. 6, pp. 503-516, 2021.

I. Martinčević, P. Brlek, N. Domjan: ROLE OF MaaS IN TOURISM

service. In terms of the use of the MaaS service when planning and going on a trip, $98 \%$ of respondents have never used the MaaS service, while only $2 \%$ have used the MaaS service. Respondents answered questions related to MaaS features by selecting the offered answer and giving their assessments regardless of whether they have an application installed on their phone or not. Results related to the Maas construct is divided into three levels: travel planning, ticket payment and purchase, and other functionalities shown through the following tables and figures.

Table 1 shows descriptive statistics for the construct "MaaS service: Travel Planning" which consists of eight particles: PP1, PP2, PP3, PP4, PP5, PP6, PP7, PP8. The highest mean value have particles PP4 (Sending real-time updates when on my route are delays) and PP5 (Proposing routes including my private car) (3.96). Particle PP3 has the lowest mean value (Indication of the environmental impact of each proposed mode of transport (PP3) (3.36).

Table 1. Descriptive statistics for the construct „MaaS service: Travel planning“

\begin{tabular}{lccccc}
\hline & $\mathrm{N}$ & MIN & MAX & MEAN & STD.DEV. \\
\hline PP1 & 405 & 1 & 5 & 3,45 & 1,178 \\
PP2 & 1 & 5 & 3,67 & 1,127 \\
PP3 & 405 & 1 & 5 & 3,36 & 1,118 \\
PP4 & 405 & 1 & 5 & 3,96 & 1,123 \\
PP5 & 405 & 1 & 5 & 3,96 & 1,075 \\
PP6 & 405 & 1 & 5 & 3,50 & 1,170 \\
PP7 & 405 & 1 & 5 & 3,87 & 1,152 \\
PP8 & 405 & 1 & 5 & 3,77 & 1,208 \\
\hline
\end{tabular}

Source: authors' research, 2021.

Figure 1 shows the obtained mean values for the observed construct „MaaS service: Travel planning“".

Figure 1. Mean value for construct „MaaS service: Travel planning”

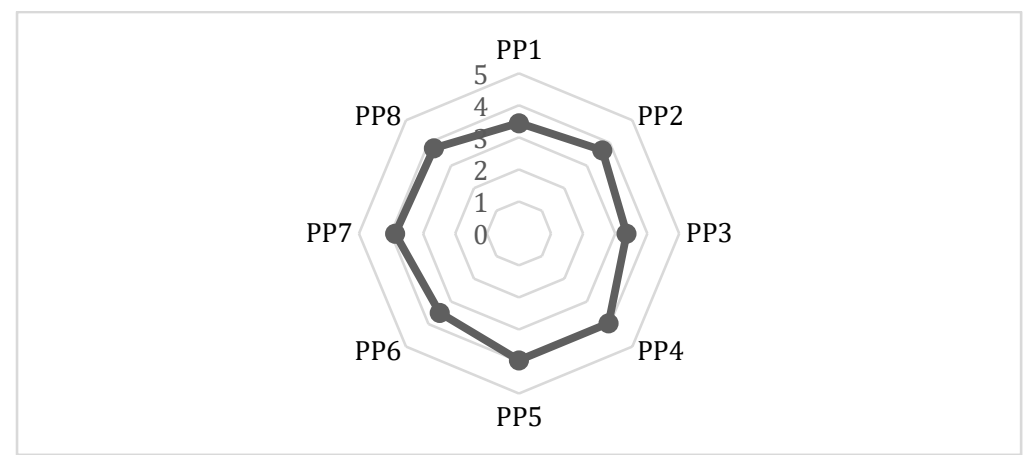

Source: authors' research, 2021.

Table 2 shows the structure of respondents' responses for the construct "MaaS service: Travel planning". Most respondents, more than half, give their answers within the Likert 
ToSEE - Tourism in Southern and Eastern Europe, Vol. 6, pp. 503-516, 2021.

I. Martinčević, P. Brlek, N. Domjan: ROLE OF MaaS IN TOURISM

scale of answers 4 (mostly important to me) and answers 5 (very important to me) where most respondents 37\% of them mostly agree with the statement PP2 (Suggesting transport mode combinations to save travel costs) and the statement PP5 (Suggesting routes that include my private car) $34 \%$ of them, while for respondents very important statement is PP4 (Sending real-time updates when there are delays on the route) for $40 \%$ of them.

Table 2. Structure of respondents' responses for construct MaaS service: Travel planning

\begin{tabular}{lcccccc}
\hline MaaS service: Travel planning & 1 & 2 & 3 & 4 & 5 & Total \\
\hline $\begin{array}{l}\text { Proposing routes that combine modes of } \\
\text { public and private transport (PP1) }\end{array}$ & $9 \%$ & $9 \%$ & $29 \%$ & $33 \%$ & $20 \%$ & $100 \%$ \\
$\begin{array}{l}\text { Suggesting transport mode combinations to } \\
\text { save travel costs (PP2) }\end{array}$ & $7 \%$ & $7 \%$ & $24 \%$ & $37 \%$ & $25 \%$ & $100 \%$ \\
$\begin{array}{l}\text { Indication of the environmental impact of } \\
\text { each proposed mode of transport (PP3) }\end{array}$ & $8 \%$ & $11 \%$ & $34 \%$ & $31 \%$ & $16 \%$ & $100 \%$ \\
$\begin{array}{l}\text { Sending real-time updates when there are } \\
\text { delays on the route (PP4) }\end{array}$ & $6 \%$ & $3 \%$ & $21 \%$ & $30 \%$ & $40 \%$ & $100 \%$ \\
$\begin{array}{l}\text { Suggesting routes that include my private } \\
\text { car (PP5) }\end{array}$ & $5 \%$ & $3 \%$ & $20 \%$ & $34 \%$ & $38 \%$ & $100 \%$ \\
$\begin{array}{l}\text { Suggesting routes that combine my private } \\
\text { car with other modes of transport (PP6) }\end{array}$ & $8 \%$ & $10 \%$ & $29 \%$ & $31 \%$ & $22 \%$ & $100 \%$ \\
$\begin{array}{l}\text { Display of waiting time for arrival of mode } \\
\text { of transport (PP7) }\end{array}$ & $6 \%$ & $5 \%$ & $21 \%$ & $31 \%$ & $37 \%$ & $100 \%$ \\
$\begin{array}{l}\text { Showing the location of the vehicle I will } \\
\text { use (PP8) }\end{array}$ & $9 \%$ & $3 \%$ & $23 \%$ & $31 \%$ & $34 \%$ & $100 \%$ \\
\hline
\end{tabular}

Source: authors' research, 2021., according to European Union's Horizon 2020 research and innovation programme under grant agreement No 723176, 2018.

The above answer structure for the construct "MaaS service: Travel planning" is shown graphically in Figure 2.

Figure 2. Graphic representation of the structure of the answers for the construct "MaaS service: Travel planning"

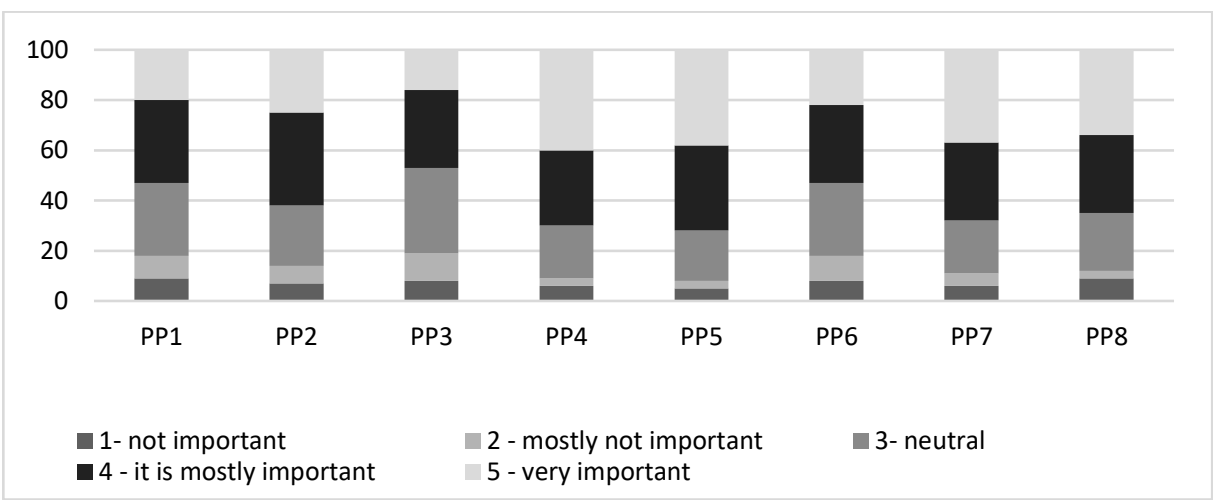

Source: authors' research, 2021. 
ToSEE - Tourism in Southern and Eastern Europe, Vol. 6, pp. 503-516, 2021.

I. Martinčević, P. Brlek, N. Domjan: ROLE OF MaaS IN TOURISM

Table 3 shows descriptive statistics for the construct "MaaS service: Paying and buying tickets" that consist of three particles: PK1, PK2, PK3. The mean value for PK1 (Possibility to buy all transport tickets in one place) is (3.96), for PK2 (Possibility to connect a bank card so that all tickets can be paid) (3.92), and for PK3 (All my transport tickets are on mobile) is (3.88).

Table 3. Descriptive statistics for the construct „MaaS service: Paying and buying tickets

\begin{tabular}{lccccc}
\hline & N & MIN & MAX & MEAN & STD.DEV. \\
\hline PK1 & 405 & 1 & 5 & 3,92 & 1,159 \\
PK2 & 405 & 1 & 5 & 3,92 & 1,149 \\
PK3 & 405 & 1 & 5 & 3,88 & 1,178 \\
\hline
\end{tabular}

Source: authors' research, 2021.

Figure 3 shows the obtained mean values for the observed constructs "MaaS service: Paying and buying tickets".

Figure 3. Mean value for construct „MaaS service: Paying and buying tickets”

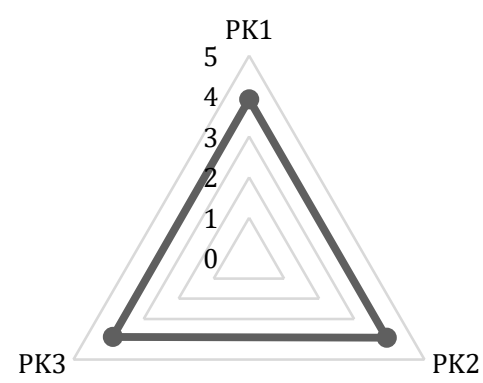

Source: author's research, 2021.

Table 4 shows the respondents' response structure for the construct "MaaS service Paying and buying tickets". Most respondents, more than half, give their answers within the Likert scale of answers 4 (mostly important to me) and answers 5 (very important to me). Most respondents believe and claim that the statement PK2 is mostly important for them (Possibility to connect a bank card so that all cards can be paid) $31 \%$ of them, while the statement PK1 (Possibility to buy all transport tickets in one place) is very important for $40 \%$ of them. 
ToSEE - Tourism in Southern and Eastern Europe, Vol. 6, pp. 503-516, 2021.

I. Martinčević, P. Brlek, N. Domjan: ROLE OF MaaS IN TOURISM

Table 4. Structure of respondents' responses for construct "MaaS service: Paying and buying tickets"

\begin{tabular}{lcccccc}
\hline MaaS service: Paying and buying tickets & 1 & 2 & 3 & 4 & 5 & Total \\
\hline $\begin{array}{l}\text { Possibility to buy all transport tickets in one } \\
\text { place (PK1) }\end{array}$ & $6 \%$ & $5 \%$ & $20 \%$ & $29 \%$ & $40 \%$ & $100 \%$ \\
$\begin{array}{l}\text { Possibility to connect a bank card so that all } \\
\text { cards can be paid (PK2) }\end{array}$ & $6 \%$ & $4 \%$ & $20 \%$ & $31 \%$ & $39 \%$ & $100 \%$ \\
$\begin{array}{l}\text { All my transport tickets are on my mobile } \\
\text { phone (PK3) }\end{array}$ & $7 \%$ & $5 \%$ & $20 \%$ & $29 \%$ & $39 \%$ & $100 \%$ \\
\hline
\end{tabular}

Source: authors' research, 2021., according to European Union's Horizon 2020 research and innovation programme under grant agreement No 723176, 2018.

The above answer structure for the construct "MaaS service: Paying and buying tickets" is shown graphically in Figure 4.

Figure 4. Graphic representation of the structure of the answers for the construct "MaaS service: Paying and buying tickets"

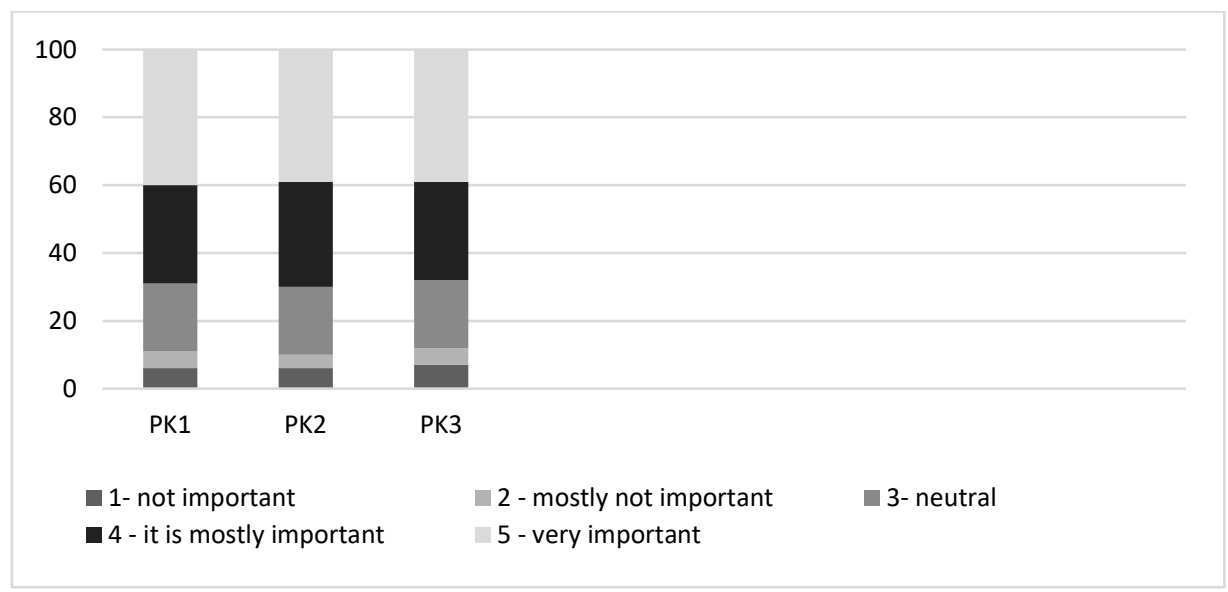

Source: authors' research, 2021.

Table 5 shows descriptive statistics for the construct "MaaS service: Other functionalities" and consist of seven particles: OF1, OF2, OF3, OF4, OF5, OF6, OF7. The highest mean value has the particle OF6 (Possibilities to set targets for reducing travel costs) (3.73) while the lowest mean value has the particle OF1 (Possibility to view travel statistics for each week / month / year) (3.09). 
ToSEE - Tourism in Southern and Eastern Europe, Vol. 6, pp. 503-516, 2021.

I. Martinčević, P. Brlek, N. Domjan: ROLE OF MaaS IN TOURISM

Table 5. Descriptive statistics for the construct „MaaS service: Other functionalities"

\begin{tabular}{lccccc}
\hline & N & MIN & MAX & MEAN & STD.DEV. \\
\hline OF1 & 405 & 1 & 5 & 3,09 & 1,085 \\
OF2 & 405 & 1 & 5 & 3,59 & 1,115 \\
OF3 & 405 & 1 & 5 & 3,34 & 1,089 \\
OF4 & 405 & 1 & 5 & 3,49 & 1,131 \\
OF5 & 405 & 1 & 5 & 3,46 & 1,180 \\
OF6 & 405 & 1 & 5 & 3,73 & 1,124 \\
OF7 & 405 & 1 & 5 & 3,63 & 1,148 \\
\hline
\end{tabular}

Source: authors' research, 2021

Figure 5 shows the obtained mean values for the observed constructs "MaaS services: Other functionalities".

Figure 5. Mean value for construct „MaaS service: Other functionalities”

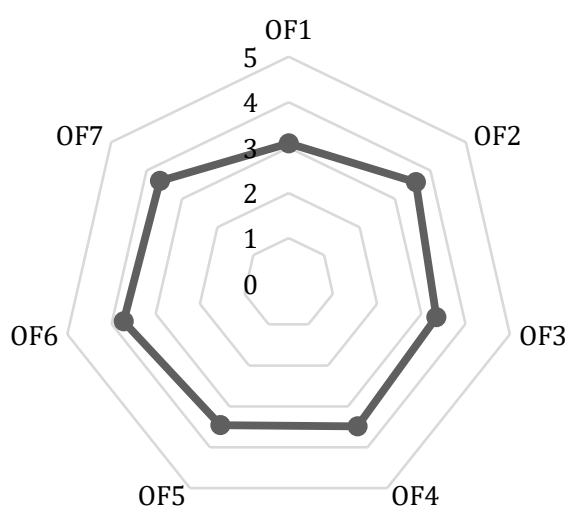

Source: authors' research, 2021.

Table 6 shows the respondents' response structure for the construct "MaaS service: Other functionalities". Most respondents are neutral (neither important to me nor unimportant) regarding the OF1 statement (Ability to view travel statistics for each week / month / year) (45\%). The statements OF2 (Possibility to take the bill for each trip) and OF6 (Possibilities of setting travel goals to reduce travel costs) are mostly important to the majority of respondents (35\%), while the statement OF6 is very important for $28 \%$ of them. 
ToSEE - Tourism in Southern and Eastern Europe, Vol. 6, pp. 503-516, 2021.

I. Martinčević, P. Brlek, N. Domjan: ROLE OF MaaS IN TOURISM

Table 6. Structure of respondents' responses for construct "MaaS service: Other functionalities"

\begin{tabular}{lcccccc}
\hline MaaS service: Other functionalities & 1 & 2 & 3 & 4 & 5 & Total \\
\hline $\begin{array}{l}\text { Ability to view travel statistics for each } \\
\text { week / month / year (OF1) }\end{array}$ & $10 \%$ & $13 \%$ & $45 \%$ & $21 \%$ & $11 \%$ & $100 \%$ \\
$\begin{array}{l}\text { Possibility to take the bill for each trip } \\
\text { (OF2) }\end{array}$ & $7 \%$ & $5 \%$ & $30 \%$ & $35 \%$ & $22 \%$ & $100 \%$ \\
$\begin{array}{l}\text { Possibility to create and have a family } \\
\text { account (OF3) }\end{array}$ & $7 \%$ & $12 \%$ & $38 \%$ & $27 \%$ & $16 \%$ & $100 \%$ \\
$\begin{array}{l}\text { Possibility to share the trip with friends } \\
\text { and family during the trip (OF4) }\end{array}$ & $8 \%$ & $7 \%$ & $33 \%$ & $32 \%$ & $20 \%$ & $100 \%$ \\
$\begin{array}{l}\text { Possibility to order food delivery during } \\
\text { the trip (OF5) }\end{array}$ & $8 \%$ & $11 \%$ & $29 \%$ & $31 \%$ & $21 \%$ & $100 \%$ \\
$\begin{array}{l}\text { Possibilities of setting travel goals to } \\
\text { reduce travel costs (OF6) }\end{array}$ & $7 \%$ & $5 \%$ & $25 \%$ & $35 \%$ & $28 \%$ & $100 \%$ \\
$\begin{array}{l}\text { Possibility of rewarding when choosing } \\
\text { green modes of transport (OF7) }\end{array}$ & $8 \%$ & $5 \%$ & $28 \%$ & $34 \%$ & $25 \%$ & $100 \%$ \\
\hline
\end{tabular}

Source: authors' research, 2021., according to European Union's Horizon 2020. research and innovation programme under grant agreement No 723176, 2018.

The above answer structure for the construct "MaaS service: Other functionalities" is shown graphically in Figure 6.

Figure 6. Graphic representation of the structure of the answers for the construct "MaaS service: Other functionalities"

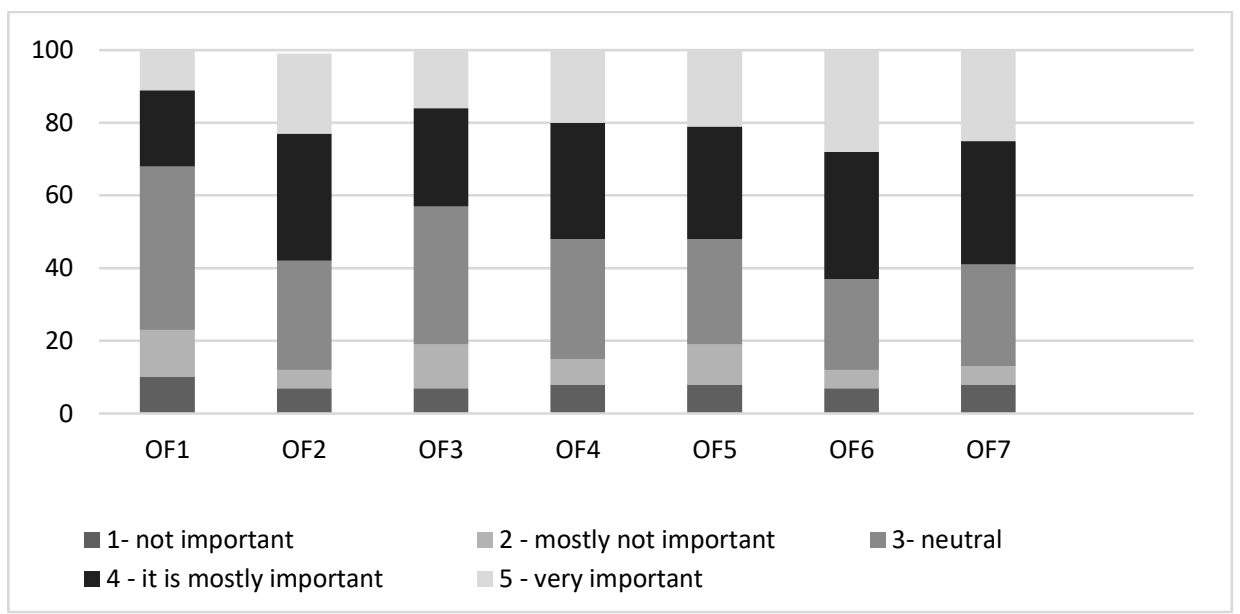

Source: authors' research, 2021.

The results of the research show that, although only $2 \%$ of citizens are familiar with the MaaS service, the recognition of elements of the MaaS service (travel planning, ticket payment and purchase, and other functionalities) by citizens are stated as important factors that greatly facilitate and influence the greater functionality of travel and mobility. 
ToSEE - Tourism in Southern and Eastern Europe, Vol. 6, pp. 503-516, 2021.

I. Martinčević, P. Brlek, N. Domjan: ROLE OF MaaS IN TOURISM

\section{LIMITATIONS AND RECOMMENDATIONS FOR FURTHER RESEARCH}

After conducting research and presenting descriptive results related to the Maas construct, which is divided into three levels: travel planning, ticket payment and purchase, and other functionalities, it is possible to highlight the obstacles of this research and make recommendations for further research. Given the purpose and goal of the research, the number of elements within the observed constructs can be reduced or increased, but also changed. The sample of the research was the general population of the Republic of Croatia in order to examine the awareness of citizens about new ways of sustainable mobility and MaaS service. The research showed that the respondents are not sufficiently familiar with the MaaS service, but by evaluating the elements of MaaS service, they indicate its importance and functionality in travel planning. Considering the this is the first such research conducted in the Republic of Croatia about the new concept the MaaS service, the results show the real situation regarding the awereness and use of the MaaS service, which is currently not at a satisfactory level. Despite the above limitations regarding the lack of information about the concept of the MaaS service, it is necessary to point out the recommendations for further research. As this is the first such survey that examines the MaaS service, it would be desirable to repeat the same research (in a shorter period of time) in order to examine whether there is a shift and greater awareness and use of MaaS service among citizens. Also, this research was conducted in the territory of the Republic of Croatia, so for future research it would be desirable to include other EU countries as well as neighboring countries of the Republic of Croatia in order to be able to compare data according to certain criteria and areas.

\section{CONCLUSION}

The conducted research about MaaS service in the Republic of Croatia indicates insufficient awareness and use of the MaaS service as a new concept aimed at sustainable mobility. The survey included 405 respondents, of which only $2 \%$ are familiar with and use the service. As this is the first such research in the Republic of Croatia that explores new concepts of sustainable mobility and places emphasis on the MaaS service which is the center area of this research, we can argue about a significant scientific contribution which leaves space for further research in this area. Through the applicative contribution of this scientific paper, the idea and goal was to bring closer to the citizens of the Republic of Croatia the importance and functionality of new concepts of sustainable mobility and, above all, MaaS services. By analyzing the relevant scientific literature and by the results of empirical research, it is possible to conclude that there is currently insufficient awareness and use of MaaS service among citizens, but through the evaluation of the elements provided by the MaaS service, the recognition and appreciation of the concept is visible, which should ultimately lead to its increasing application. 
ToSEE - Tourism in Southern and Eastern Europe, Vol. 6, pp. 503-516, 2021.

I. Martinčević, P. Brlek, N. Domjan: ROLE OF MaaS IN TOURISM

\section{REFERENCES}

Alexandre, L. (2020), How can MaaS improve the travel experience?, viewed 03 May 2021, https://lyko.blog/en/maas-improve-travel-experience/

Alyavina, E., Nikitas, A. and Njoya, E. (2020), "Mobility as a Service and sustainable travel behaviour: A thematic analysis study", Transportation Research Part F 73, pp. 362-381, viewed 29 April 2021 , www.elsevier.com/locate/trf

BMaaS Contributor (2018), What are the Benefits of Mobility as a Solution for Commuters?, viewed 06 May 2021, https://www.businessmaas.com/apps/what-are-the-benefits-of-mobility-as-a-solution-forcommuters/

Bonetti, P. (2018), Get to know the services making mobility easier and more accessible for all, viewed 03 May 2021, https://360.here.com/get-to-know-the-services-making-mobility-easier-and-moreaccessible-for-all

Bude, P. (2016). Global smart infrastructure - Smart city transformation, viewed 28 April 2021, http://www.reportlinker.com/p03305857-summary/Global-SmartInfrastructure-Smart-CityTransformation.html

CIVITAS (2016), Mobility-as-a-Service: A new transport model, viewed 27 April 2021, http://civitas.eu/content/civitas-insight-18-mobility-service-new-transport-model

Duggan, C. (2019), An Exploration of Some of the Benefits of Mobility as a Service, viewed 06 May 2021, https://www.field-dynamics.co.uk/the-benefits-of-mobility-as-a-service/

EPOMM, European Platform on Mobility Management (2017), The Role of Mobility as a Service in Mobility Management, viewed 06 May 2021, http://www.epomm.eu/newsletter/v2/content/2017/1217_2/doc/eupdate_en

ERTICO - ITS Europe (2019), Mobility as a Service (MaaS) and Sustainable Urban Mobility Planning, viewed 28 april 2021, https://www.eltis.org/sites

Goodall, W., Dovey Fishman, T., Bornstein, J. and Bonthron, B. (2017), The rise of mobility as a Service reshaping how urbanites get around, viewed 28 April 2021, https://www2.deloitte.com

Hodgons, J. (2021), Rebuilding Smart Mobility: Shared, safe and profitable, ABI research, trusted intelligence since 1990, published March 2021, viewed 03 May 2021, https://www.here.com/sites/g/files/odxslz166/files/2021-04/HERE_whitepaperRebuilding smart mobility_ABI

Holmberg, P.-E., Collado, M., Sarasini, S. and Williander, M. (2016), Mobility as a Service-MaaS. Describing the framework (Final report MaaS framework). Göteborg: Viktoria Swedish ICT, viewed 27 April 2021, https://trid.trb.org/view/1506448

House of Commons Transport Committee (2018), Mobility as a Service: Eighth Report of Session 2017-19, viewed 29 April 2021, https://publications.parliament.uk/pa/cm201719/cmselect/cmtrans/590/590

Karlsson, I.C.M., Sochor, J. and Strömberg, H. (2016), "Developing the 'Service' in Mobility as a Service experiences from a field trial of an innovativetravelbrokerage", Transportation Research Procedia, Vol. 14, pp. 265-273, viewed 03 May 2021, https://doi.org/10.1016/j.trpro.2016.05.273

La Roca, R.A. (2016), Tourism and Mobility. Best Practices and Conditions to Improve Urban Livability. Article in TeMA: Journal of Land Use, Mobility and Environment, published December 2015 , viewed 03 May 2021, https://www.researchgate.net/publication/293175478

Li, Y. and Voege, T. (2017), "Mobility as a Service (MaaS): Challenges of Implementation and Policy Required", Journal of Transportation Technologies, Vol. 7, pp. 95-106. doi: 10.4236/jtts.2017.72007

Lopez-Cordova, E. (2020). "Digital Platforms and the Demand for International Tourism Services", Policy $\begin{array}{llllll}\text { Research Working } & \text { Paper } & \text { 9147, } & \text { viewed }\end{array}$ http://documents1.worldbank.org/curated/en/724941581621885483

MaaS Alliance (2019), MaaS Monitor: Maas as the mobility online platform, viewed 29 April 2021,https://maas-alliance.eu/2019/12/06/maas-monitor-maas-as-the-mobility-online-platform/

Tchervenkova, G. (2000), Mobility concepts and tourism travel, Munich, GRIN Verlag, viewed 03 May 2021, https://www.grin.com/document/47221

Whim (2019). A Brief History of MaaS Global, the company behind the Whim app, viewed 27 April 2021 , https://whimapp.com/helsinki/en/history-of-maas-global/ 
ToSEE - Tourism in Southern and Eastern Europe, Vol. 6, pp. 503-516, 2021.

I. Martinčević, P. Brlek, N. Domjan: ROLE OF MaaS IN TOURISM

Ivana Martinčević, $\mathrm{PhD}$, Assistant Professor

University North

Department of Logistics and Sustainable Mobility

Trg Žarka Dolinara 1, 48000 Koprivnica, Croatia +385 98/791-015

ivana.martincevic@unin.hr

Predrag Brlek, PhD, Assistant Professor

University North

Department of Logistics and Sustainable Mobility

Trg Žarka Dolinara 1, 48000 Koprivnica, Croatia

+385 98/1716-790

predrag.brlek@unin.hr

Nives Domjan, mag.ing.traff.

University North

Department of Logistics and Sustainable Mobility

Trg Žarka Dolinara 1, 48000 Koprivnica, Croatia +385 99/278-9666

nidomjan@unin.hr 